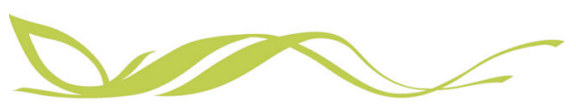

COMMUNICATIONS

EARTH\&ENMRONMENT

ARTICLE

https://doi.org/10.1038/s43247-020-00028-z

OPEN

\title{
Deglacial to Holocene variability in surface water characteristics and major floods in the Beaufort Sea
}

Junjie Wu (10 ${ }^{1 凶}$, Ruediger Stein (10) ${ }^{1,2,3}$, Kirsten Fahl (10 1, Nicole Syring ${ }^{1}$, Seung-II Nam (10) ${ }^{4}$, Jens Hefter (10 1, Gesine Mollenhauer (10) ${ }^{1,2,3} \&$ Walter Geibert (i) ${ }^{1}$

Surface water characteristics of the Beaufort Sea have global climate implications during the last deglaciation and the Holocene, as (1) sea ice is a critical component of the climate system and (2) Laurentide Ice Sheet meltwater discharges via the Mackenzie River to the Arctic Ocean and further, to its outflow near the deep-water source area of the Atlantic Meridional Overturning Circulation. Here we present high-resolution biomarker records from the southern Beaufort Sea. Multi-proxy biomarker reconstruction suggests that the southern Beaufort Sea was nearly ice-free during the deglacial to Holocene transition, and a seasonal sea-ice cover developed during the mid-late Holocene. Superimposed on the long-term change, two events of high sediment flux were documented at ca. 13 and $11 \mathrm{kyr} \mathrm{BP}$, respectively. The first event can be attributed to the Younger Dryas flood and the second event is likely related to a second flood and/or coastal erosion.

\footnotetext{
${ }^{1}$ Alfred Wegener Institute Helmholtz Centre for Polar and Marine Research, Am Alten Hafen 26, 27568 Bremerhaven, Germany. ${ }^{2}$ Department of Geosciences (FB5), University of Bremen, Klagenfurter Strasse 4, 28359 Bremen, Germany. ${ }^{3}$ MARUM-Center for Marine Environmental Sciences, University of Bremen, 28359 Bremen, Germany. ${ }^{4}$ Korea Polar Research Institute, 26 Songdomirae-ro, Yeonsu-gu, 21990 Incheon, Republic of Korea.

凶email: junjie.wu@awi.de
} 
A rctic sea ice, characterized by strong seasonal variations, is a critical component in the global climate system as sea ice has direct impact on climate change by regulating energy exchanges between the atmosphere and ocean. The variability of sea ice contributes to changes in the albedo effect, the freshwater system, and the surface energy budget in the Arctic Ocean $^{1-4}$. In a positive ice-albedo feedback, increases of absorbed energy result in further sea-ice melting ${ }^{5,6}$. Increased melting and sea-ice export can slow down the Atlantic Meridional Overturning Circulation (AMOC) as well as the poleward heat transport ${ }^{7}$. Due to these complex feedback processes, the Arctic is both a contributor to climate change and a region that is most strongly affected by global warming $3,4,8,9$.

Arctic sea ice has reduced drastically over the past few decades, recognized in both satellite observations and model simulations ${ }^{8,10,11}$. Since 1980 , the sea-ice cover has had a mean annual areal reduction of $\sim 20 \%$ and an even stronger decrease of $\sim 30 \%$ in September ${ }^{7}$. This decrease in sea ice is also suggested to be the driver of frequent cold extremes over Eurasia in the past two decades ${ }^{12}$. Historical observations spanning the last few decades are deficient in length to decipher the processes of accelerated sea-ice retreat, thus longer-term and high-resolution proxy records of paleoenvironmental changes are needed. During transition from the last deglacial to the Holocene, the climate system underwent numerous abrupt changes, particularly the Bølling/Allerød (B/A) interstadial and the Younger Dryas (YD) stadial. The Holocene, not concluded yet, has experienced a significantly warmer period during its early stage (Early Holocene Thermal Maximum) ${ }^{13}$. Causes of the abrupt climate change are not fully understood, hence special emphasis on the transition from the deglacial into the Holocene is of significance to understand the forcing mechanisms of the climate system. In this context, the Arctic marginal seas characterized by strong seasonal variability in sea-ice cover, primary productivity, and terrigenous (riverine) input are very sensitive to environmental changes and thus of major importance for paleoclimate reconstructions. One of these marginal seas is the Beaufort Sea (Fig. 1), which we focus on in this paper.

Today, the Mackenzie River is the largest fluvial source of water and sediment into the Beaufort Sea, characterized by water discharge of $316 \mathrm{~km}^{3} \mathrm{yr}^{-1}$ and sediment flux of 124-128 Mt yr (Ref. ${ }^{14}$; Figs. 1 and 2). Since the drainage system was established during the late Wisconsinan (i.e., Marine Isotope Stage 2) as a result of glacial erosion, it was an outlet of glacial meltwater during the last deglaciation ${ }^{15}$. During this period, a cold episode known as YD coincides with a significant reduction of AMOC caused by increased freshwater flux into the North Atlantic deepwater formation region ${ }^{16}$. The freshwater discharge has been linked to an outburst from the Lake Agassiz, and there is an ongoing debate about the pathway of this freshwater discharge, i.e., whether it drained first into the Arctic Ocean and then to the Atlantic Ocean or whether it drained directly into the Atlantic Ocean ${ }^{17-20}$ (Fig. 3). More recently, field data indicate the freshwater of Lake Agassiz could not drain northward during the $\mathrm{YD}^{21}$, while model simulations suggest the meltwater drainage via Mackenzie River (northwestern outlet) as a competitive candidate triggering the YD cooling ${ }^{17,22}$. Following the YD cold period, field data from the Fort McMurray and the Mackenzie Delta point to a post-YD flood from proglacial lakes, which drained through the Mackenzie River to the Arctic Ocean during the early Holocene ${ }^{23,24}$. The timing of the flood coincides with the Preboreal Oscillation $(\mathrm{PBO})$ and thus it has been proposed as the trigger of $\mathrm{PBO}^{25}$. Above-mentioned events are of significance to climate change, but corresponding marine records are scarce. Therefore, high-resolution records are needed to identify these events and the timing of their inception.

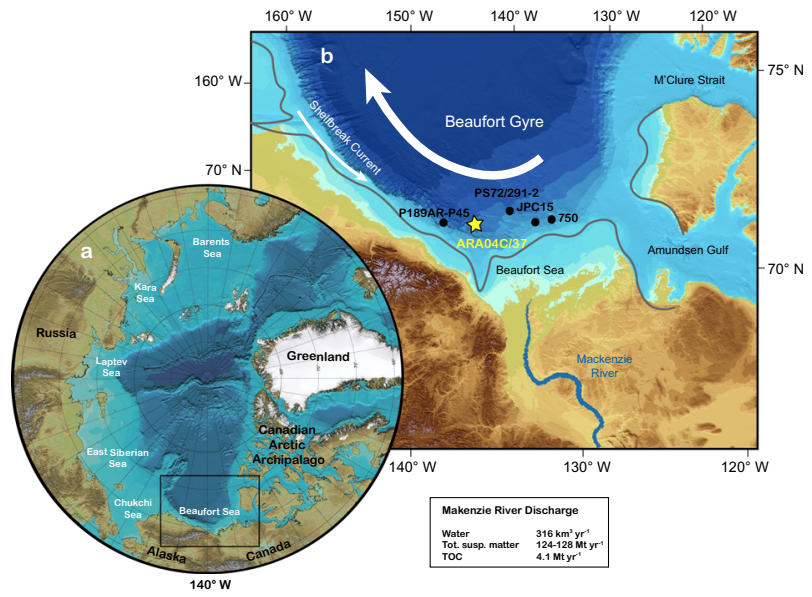

Fig. 1 Overview of the Arctic Ocean and core location in this study. a overview of the Arctic Ocean and the study area (black box). b regional map presents the Beaufort Sea surface water circulation (white arrows), the Mackenzie River (blue line), and the coast at 14 kyr BP 96 (gray lines). Location of Core ARA04C/37 is indicated by yellow star and other sediment cores discussed in the text (core information can be found in Supplementary Table 3) are indicated by black circles. Mackenzie River discharge of water, total suspended matter, and total organic carbon is listed in the box ${ }^{14,94}$.

Here, we apply a biomarker approach on a well-dated sediment core from the Beaufort Sea directly off the Mackenzie River (Fig. 1), covering the time interval of the last deglaciation and the Holocene. Multiple biomarker proxies are used to reconstruct the changes in sea ice, sea surface temperature (SST), primary productivity, and terrigenous input. Based on our records, we demonstrate that (1) the Beaufort Sea region was nearly ice free with variable SSTs during the last deglaciation and the early Holocene, (2) sea-ice cover developed during the mid-late Holocene, coinciding with a drop in terrigenous sediment flux, SST, and primary production, and (3) two major events, characterized by prominent maxima in sediment flux, occurred at $12.83 \pm 0.15$ and ca. $11 \mathrm{kyr}$ вр. Whereas the former is related to the YD flood event, the origin of the second event is related to a post-YD flood and/or coastal erosion.

\section{Results}

Chronology and approach. Core ARA04C/37 was recovered during the 2013 Araon Cruise ARA04C ${ }^{26}$ at the Beaufort Sea continental slope off the Mackenzie River $\left(70^{\circ} 38.0212^{\prime} \mathrm{N}, 139^{\circ}\right.$ $22.0749^{\prime} \mathrm{W} ; 1173 \mathrm{~m}$ ) (Fig. 1), an area characterized by high sedimentation rates. The highest sedimentation rates occur at the Mackenzie Trough $\left(\sim 40-320 \mathrm{~cm} \mathrm{kyr}^{-1}\right)$ as well as the continental shelf and slope nearby $\left(\sim 100-200 \mathrm{~cm} \mathrm{kyr}^{-1}\right)$ (Ref. ${ }^{27}$ and references therein).

The chronology of Core ARA04C/37 was constrained by accelerator mass spectrometry (AMS) ${ }^{14} \mathrm{C}$ dating on calcareous foraminifera (planktic and mixed species; Fig. 4a and Supplementary Table 1, see "Methods") and, in the uppermost centimeters, excess ${ }^{210} \mathrm{~Pb}$. The age-depth model is established by a combination of $\mathrm{AMS}^{14} \mathrm{C}$ dates of cores ARA04C/37 and JPC15 (Fig. 4) ${ }^{19}$, based on the good correlation of $\mathrm{AMS}^{14} \mathrm{C}$ dates and magnetic susceptibility (Figs. 4a and 5a, b) from both cores (see "Methods"). Ages in this paper are provided as calendar years вр. The age-depth relation reveals a mean sedimentation rate of 27 and $100 \mathrm{~cm} \mathrm{kyr}^{-1}$ in the upper and lower $300 \mathrm{~cm}$, respectively, with high sedimentation rates in two layers near $13 \mathrm{kyr}$ BP (450-500 centimeters below seafloor (cmbsf)) and $11 \mathrm{kyr}$ вР (295-375 cmbsf). The core represents the deglacial to Holocene 

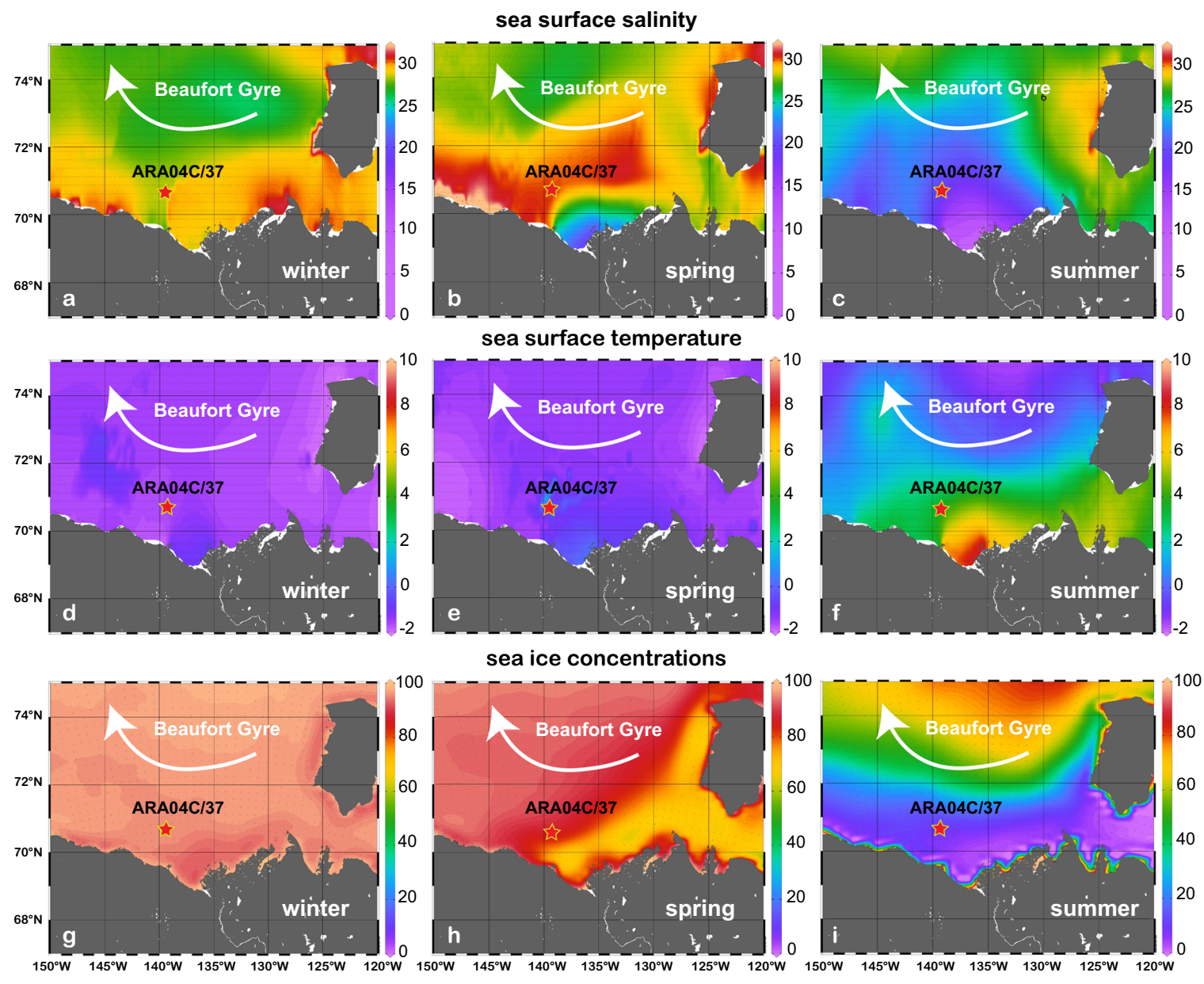

Fig. 2 Modern surface water characteristics in the Beaufort Sea. a-c modern sea surface salinity, $\mathbf{d}-\mathbf{f}$ modern sea surface temperature, $\mathbf{g}$-i modern seaice concentrations. Data of (a-f) are from the World Ocean Atlas 2013 (data source: https://www.nodc.noaa.gov/OC5/woa13/). Data of (g-i) are averaged sea-ice concentrations from 1988 to 2007 (data source: http://nsidc.org). Maps were produced with Ocean Data View software (source: http:// odv.awi.de/). White arrow represents the Beaufort Gyre circulation. Red star indicates location of Core ARA04C/37.

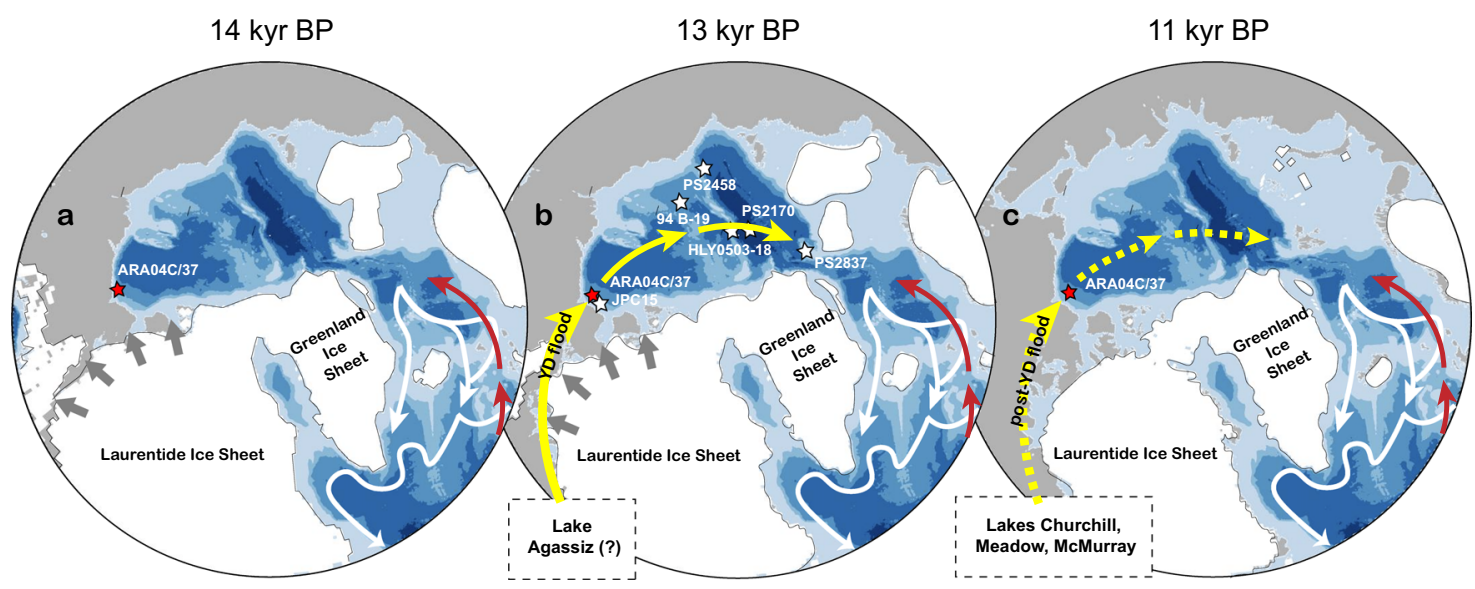

Fig. 3 Schematic illustrations of ice sheets and flood events during the deglacial to Holocene transition. a Northern Hemisphere ice-sheet extent at 14 kyr BP. b YD flood event at ca. 13 kyr BP. Yellow arrows indicate the possible route of YD flood ${ }^{58}$. White stars indicate the studied cores representing the YD flood (discussed in text) $19,35,59,71-74$. c post-YD flood event at ca. $11 \mathrm{kyr}$ BP. Dashed yellow arrows show the possible route of post-YD flood from Lake Churchill, Meadow, and McMurray 24 . In (a-c), red stars indicate location of Core ARA04C/37, and gray arrows show the melting of the LIS. Red and white arrows represent the warm Atlantic inflow to the Nordic Sea and the main bottom currents. Ice-sheet extent (white areas) outlined in (a-c) is according to Ref. ${ }^{96}$. 

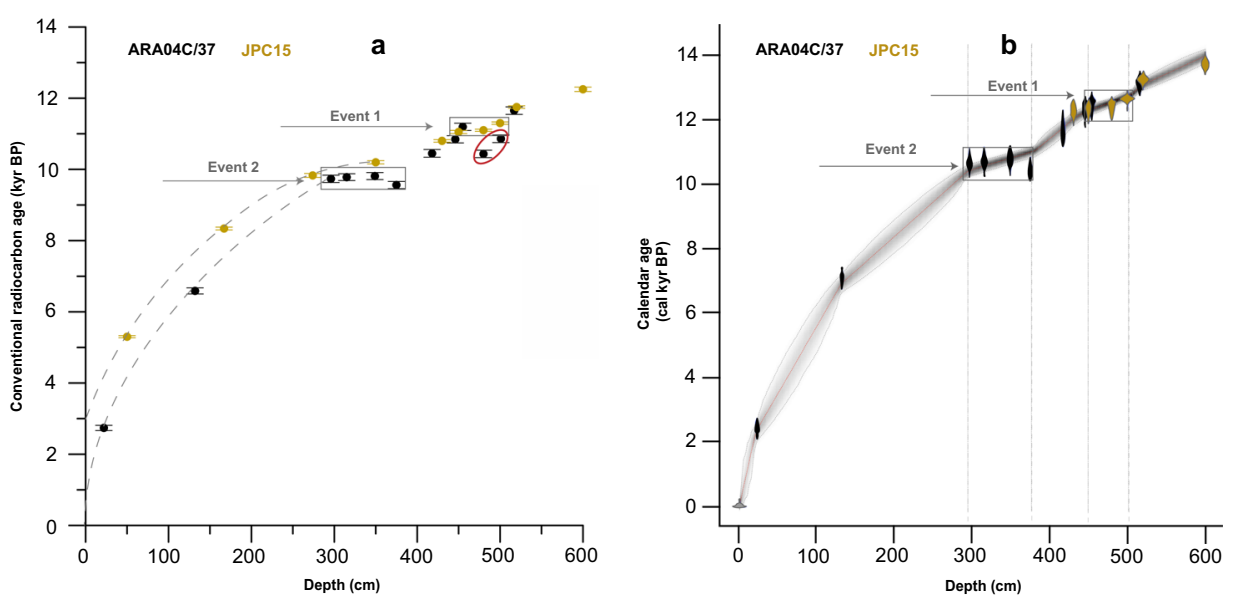

Fig. 4 Chronology. a uncalibrated $\mathrm{AMS}^{14} \mathrm{C}$ dates of Core ARA04C/37 (black dots) and Core JPC15 ${ }^{19}$ (brown dots). The vertical error bars represent the 1 sigma analytical errors. Blue boxes mark two intervals characterized by nearly constant ages, possibly related to two events. Red circle shows the excluded "outliers" of Core ARA04C/37. b Age-depth model based on Bacon ${ }^{87}$ combines ten $\mathrm{AMS}^{14} \mathrm{C}$ dates from Core ARA04C/37 (black) and six $\mathrm{AMS}^{14} \mathrm{C}$ dates from Core JPC15 (brown) ${ }^{19}$.

transition in high resolution, including the $\mathrm{B} / \mathrm{A}$ and YD intervals. This enables reconstructions of sea ice, primary productivity, SST, and freshwater discharge in the Beaufort Sea, with special emphasis on the flood events during the transition, in great detail.

The sea-ice biomarker $\mathrm{IP}_{25}{ }^{28,29}$ in combination with openwater phytoplankton biomarkers (e.g., dinosterol), the so-called "PIP ${ }_{25}$ " index, allows semi-quantitative reconstructions of sea-ice concentrations (e.g., Refs. ${ }^{30,31}$ ). The newly developed ring index $\left(\mathrm{RI}-\mathrm{OH}^{\prime}\right)$ of hydroxylated isoprenoid glycerol dialkyl glycerol tetraethers (OH-GDGTs) has been used as a potential tool to reconstruct SST in cold environments $\left(\mathrm{ca} .<15^{\circ} \mathrm{C}\right)^{32}$. The biomarkers brassicasterol and dinosterol are indicators for marine phytoplankton, whereas $ß$-sitosterol and campesterol are indicators for terrigenous input ${ }^{33-35}$. The brassicasterol in some settings has significant sources from freshwater ${ }^{33,36}$, which is the case in our study (discussed below), and hence we focus on dinosterol to reconstruct marine primary production (Supplementary Fig. 1a, b). The branched GDGTs (b-GDGT) are indicative for terrestrial input ${ }^{37-40}$, and the $\mathrm{F}_{\mathrm{C} 32} 1,15$ index (fractional abundance of $\mathrm{C}_{32}$ 1,15 -diol) is indicative for aquatic riverine input, as the $C_{32} 1,15$ diol is found particularly abundant in freshwater systems ${ }^{41-44}$. More details can be found in the method section.

Deglacial-Holocene changes in sea ice and primary production. During the deglaciation and the early Holocene ( 14-8 kyr $\mathrm{BP})$, minimum concentrations of $\mathrm{IP}_{25}$ (close to the detection limit) and low PIP $_{25}$ values point to dominantly ice-free conditions (Figs. 6a and 7c and Supplementary Fig. 1c). In such a situation, open-water conditions would be expected to promote primary production. However, concentrations of dinosterol $(\sim 1-5 \mu \mathrm{gg}$ $\mathrm{TOC}^{-1}$ ) were low to moderate, implying low primary production during the B/A interstadial (Fig. 6c). This may be explained by the fact that the Beaufort Sea itself is an oligotrophic system ${ }^{6}$, and the Bering Strait was still closed at that time ( $>13 \mathrm{kyr}$ вр), hence preventing the inflow of nutrient-rich Pacific Water ${ }^{45,46}$. Primary productivity shortly increased during the early YD (Figs. $6 \mathrm{c}$ and 7e), probably promoted by higher nutrient levels supplied by the YD flood (see below). In the early Holocene, the primary productivity experienced a rapid increase at ca. $11 \mathrm{kyr}$ BP as well as subsequent moderate increases during the early Holocene (Fig. 7e), possibly caused by high terrigenous input (including nutrients) and the total inundation of Bering Strait, respectively ${ }^{45}$. Furthermore, maximum summer insolation ${ }^{47}$ may have caused shorter sea-ice seasons at the core site. More open waters and longer duration of ice-free conditions were favorable for dinosterol production in spring and summer.

During the mid-late Holocene (8-0 kyr BP), sea ice expanded, as evidenced by elevated $\mathrm{IP}_{25}$ and $\mathrm{PIP}_{25}$ values (Figs. $6 \mathrm{a}$ and $7 \mathrm{c}$ ), which reveals an evolution from dominantly ice-free conditions $\left(\mathrm{PIP}_{25}<0.2\right)$ to more extended ice-cover conditions $\left(\mathrm{PIP}_{25}>0.8\right)$ due to decreasing summer insolation. In turn, expanded sea-ice cover and longer sea-ice duration reduced primary production since the middle Holocene (ca. 8-2.5 kyr вP) as clearly reflected in decreased dinosterol accumulation rates (Fig. 7e). The total organic carbon (TOC)-normalized dinosterol concentrations differ from dinosterol accumulation rates during the middle Holocene, increasing between ca. 8-5 kyr BP (Fig. 6c). This is attributed to simultaneous decreases in marine primary production and terrestrial input, due to sea-ice formation and decrease in river discharge, respectively. During this phase, the reduction of terrestrial organic carbon input was probably larger than that of marine organic carbon input, resulting in increased TOCnormalized dinosterol concentrations. During the late Holocene (ca. 2.5-0 kyr BP), an extended sea-ice cover even hindered primary production by limiting light penetration and nutrient release from sea-ice melt (Fig. $7 c$, e).

Reconstruction of marginal ice zones (MIZs). Abundant phytoplankton production is commonly found in MIZs. In these regions, melting sea ice releases nutrients and less-saline waters into the surface layer, forming a stable and nutrient-rich environment above the pycnocline, i.e., favorable conditions for algae blooms ${ }^{48-51}$.

Dinosterol and HBI-III (Z-isomer) (further referred to as "HBI-III"; see "Methods") have both been proposed to indicate pelagic algal production. Studies of surface sediments from different polar regions show significant enhancement of HBI-III in the MIZs ${ }^{52-55}$, while no significant difference in abundances or distributions of phytoplankton sterols was found between the MIZs and open waters ${ }^{53,54}$. Thus, the HBI-III has been proposed as an MIZ indicator by these authors. Cross-plots of $\mathrm{IP}_{25}$ vs. HBIIII show a better correlation than $\mathrm{IP}_{25}$ vs. dinosterol (Supplementary Fig. 1c, d), supporting that HBI-III is closely associated with sea-ice environments. Hence, HBI-III is more or less absent when sea-ice cover is strongly reduced or absent (i.e., between $\sim 9$ and 14 kyr вP; Fig. 7b, c, e). The $\mathrm{IP}_{25}$ and HBI-III accumulation rates peaked at ca. 5.6 and $3.5 \mathrm{kyr}$ BP (Fig. 7d, e), probably 


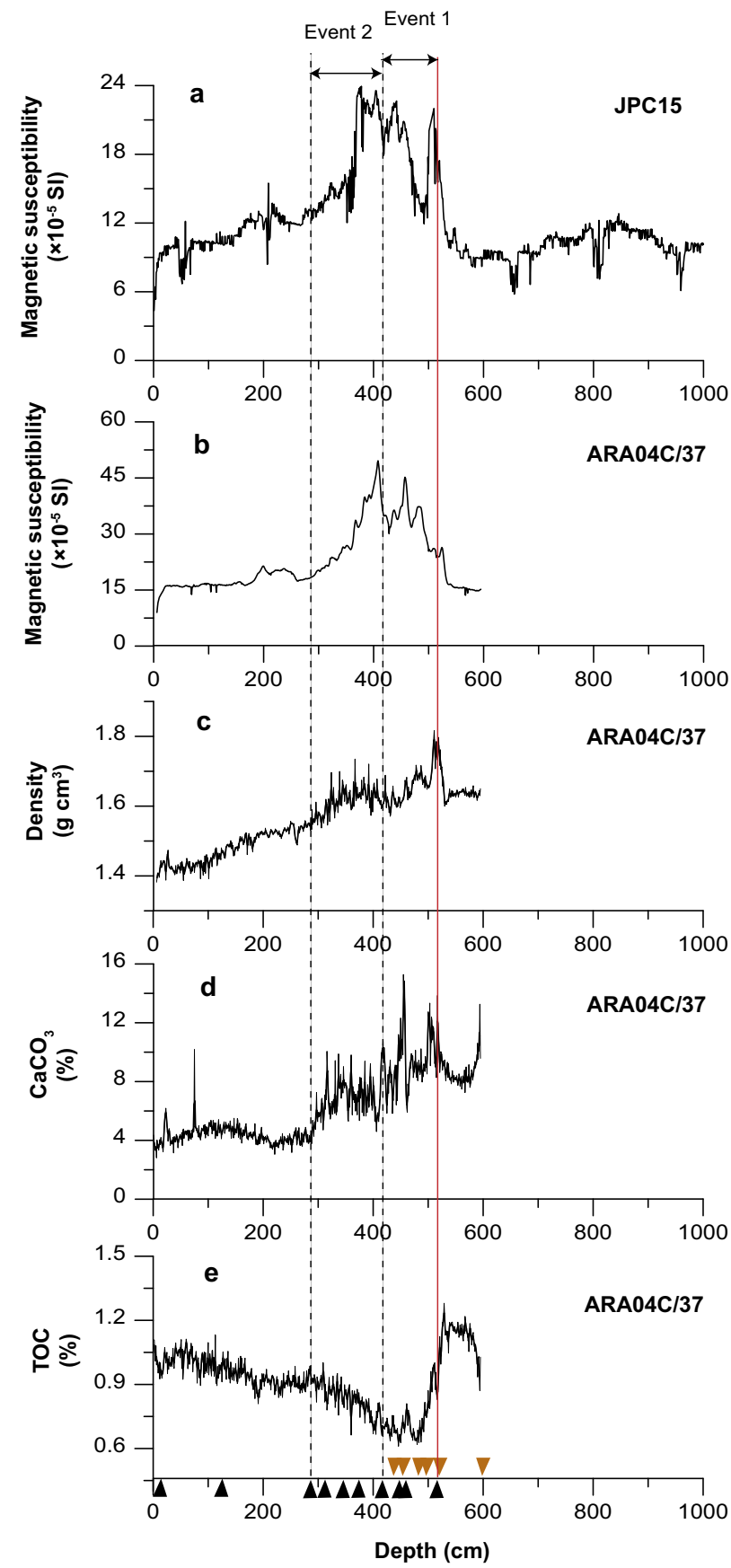

Fig. 5 Physical properties and chemical records showing two major events. a Magnetic susceptibility from Core $\mathrm{JPC}^{1} 5^{19}$. Exhibit records from Core ARA04C/37, b magnetic susceptibility, c density, $\mathbf{d ~} \mathrm{CaCO}_{3}$ content (see "Methods"), e TOC content. The vertical lines and horizonal arrows indicate the range of depth recording the two major events. The red vertical line aligns the same $\mathrm{AMS}^{14} \mathrm{C}$ dates from both cores, which indicates a good age constraint of magnetic susceptibility rise. Triangles refer to $\mathrm{AMS}^{14} \mathrm{C}$ dates used in the age-depth model, black triangles from Core ARA04C/37 (this study) and brown triangles from Core JPC15 ${ }^{19}$.

representing two periods of MIZ situations (see details in "Discussion").

Deglacial-Holocene changes in freshwater discharge. Synchronous changes (Fig. 6d, e) as well as the positive correlation (Supplementary Fig. 1a) between terrigenous biomarkers (campesterol and B-sitosterol) and brassicasterol suggest that

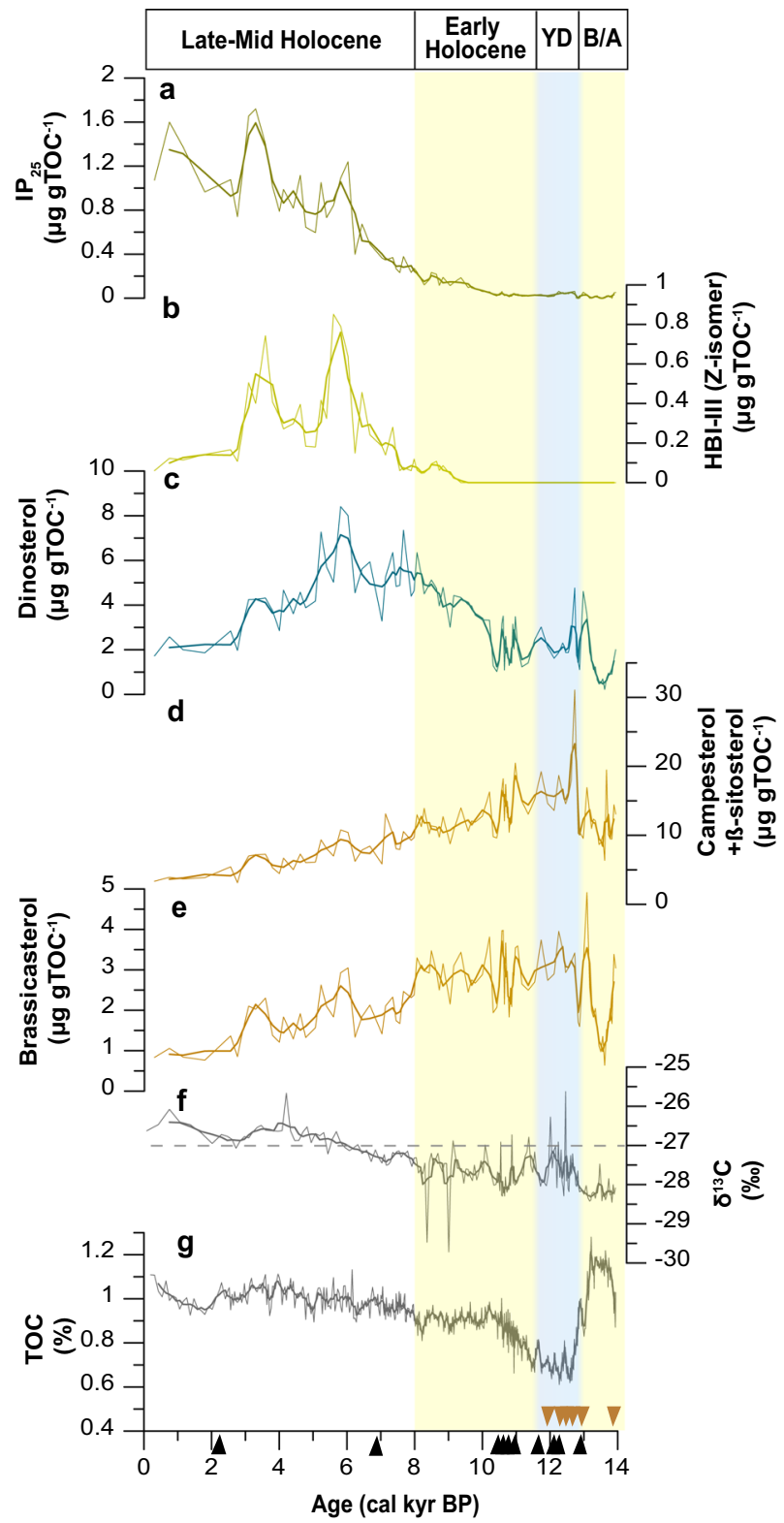

Fig. 6 Biomarker concentrations (in $\mu \mathrm{g} \mathrm{TOC}^{-1}$ ) and bulk parameters. a $\mathrm{IP}_{25}$, b $\mathrm{HBI}$-III (Z-isomer), c dinosterol, $\mathbf{d}$ terrigenous biomarker (campesterol + B-sitosterol), e brassicasterol, $\mathbf{f} \delta^{13} \mathrm{C}$ values of TOC (\%o), $\mathbf{g}$ TOC content (\%). Triangles refer to $\mathrm{AMS}^{14} \mathrm{C}$ dates used in the age-depth model (see Fig. 5).

brassicasterol in our record has a mixed source from freshwater and marine algae.

During the last deglaciation and the early Holocene ( 14-8 kyr вP), very negative $\delta^{13} \mathrm{C}_{\text {org }}$ values of -28 to $-27 \%$ (Fig. $6 \mathrm{f}$ ), relatively high terrigenous biomarker accumulation rates of 5-20 $\mu \mathrm{g} \mathrm{cm}^{-2} \mathrm{kyr}^{-1}$ (Fig. 7f), and high $\mathrm{F}_{\mathrm{C} 32 \quad 1,15}$ values up to 0.5 (Fig. $7 \mathrm{~g}$ ) all point to high terrigenous input. Relatively warm and wet environments promoted terrigenous matter transport, and low sea-level conditions resulted in a closer distance of the core site to the river mouth receiving more terrigenous matter. In the mid-late Holocene ( $\left.8-0 \mathrm{kyr} \mathrm{BP}^{\mathrm{B}}\right), \delta^{13} \mathrm{C}_{\mathrm{org}}$ values increased $(>-27 \%)$ and terrigenous biomarker accumulation rates decreased to $1 \mu \mathrm{g} \mathrm{cm}^{-2} \mathrm{kyr}^{-1}$ (Figs. 6f and 7f). Similarly, $\mathrm{F}_{\mathrm{C} 321,15}$ values decreased to 0.3 (Fig. $7 \mathrm{~g}$ ), reflecting a descending river discharge and an increasing distance of the core site to the river mouth (cf. Ref. ${ }^{56}$ ). 


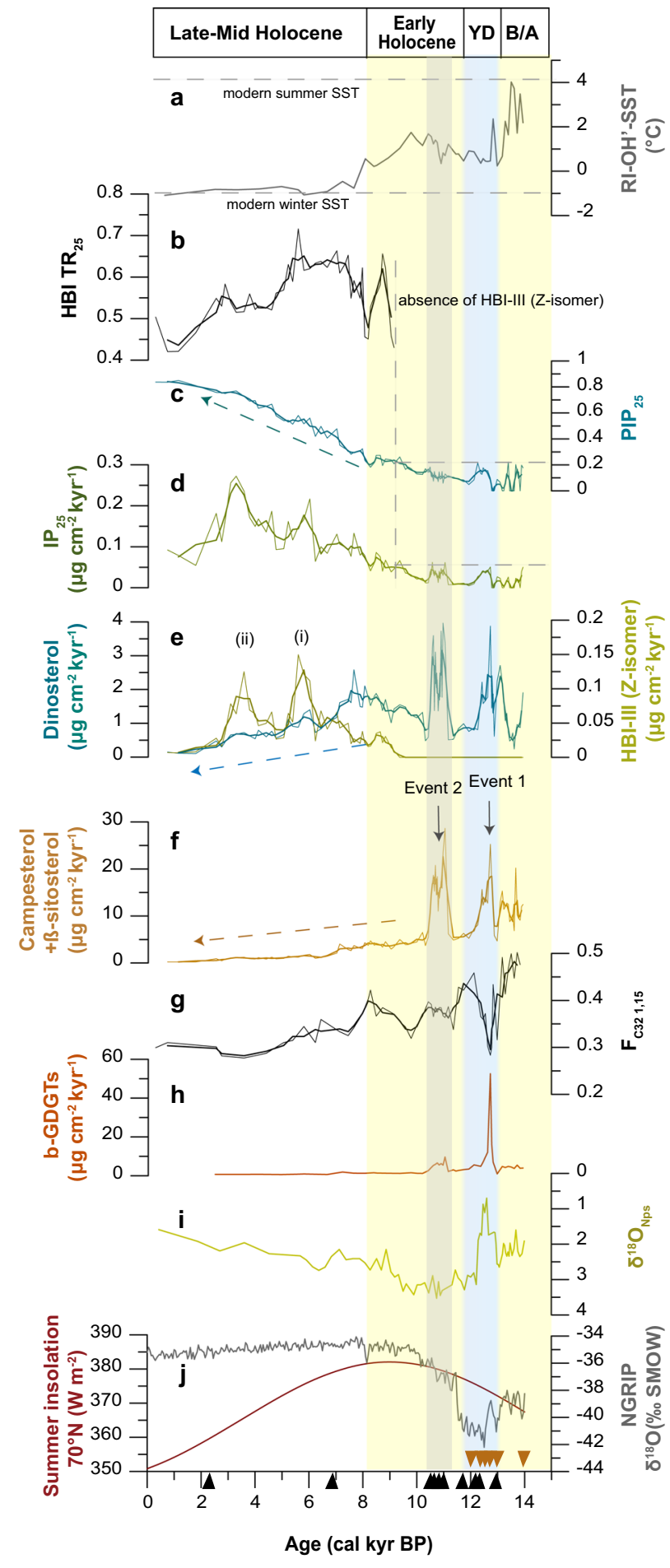

Fig. 7 Proxy records for surface water characteristics. Compilation of proxies from Core ARA04C/37 (a-h) and Core JPC15 (i). a Sea surface temperature proxy $\mathrm{RI}-\mathrm{OH}^{\prime}-\mathrm{SST}$; $\mathbf{b}$ spring phytoplankton bloom proxy $\mathrm{HBI}$ $\mathrm{TR}_{25}$; c sea-ice proxy $\mathrm{PIP}_{25}$ based on dinosterol; $\mathbf{d} \mathrm{IP}_{25}$; e dinosterol (blue) and

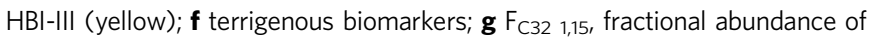
$\mathrm{C}_{32}$ 1,15-diol; $\mathbf{h}$ b-GDGTs; $\mathbf{d}-\mathbf{f}$ are biomarker accumul-

ation rates. $\mathbf{i} \delta^{18} \mathrm{O}$ values of Neogloboquadrina pachyderma in Core JPC15 ${ }^{19}$. j Summer insolation (gray) ${ }^{47}$ and $\delta^{18} \mathrm{O}$ values from NGRIP ice core (red) ${ }^{57}$. Triangles refer to $\mathrm{AMS}^{14} \mathrm{C}$ dates used in the age-depth model (see Fig. 5).
Sea surface temperature variations. During the deglaciation ( 14-11.7 kyr BP), SST values were variable and higher in comparison to the mid-late Holocene SSTs (Fig. 7a), indicating relatively warm and open-water conditions. Open-water conditions with less sea ice allowed sufficient heat exchange between ocean and atmosphere. Hence the SST variations followed the global climate history recorded in the Greenland ice core ${ }^{57}$ (Fig. 7a, j), with typical higher RI-OH'-SST values in the B/A interstadial and lower SST values during the YD stadial (Fig. 7a). In the early Holocene (11.7-8 kyr BP), RI-OH'-SST values rose again (Fig. 7a), most likely attributed to the summer insolation maximum. Additionally, the total inundation of the Bering Strait occurred at ca. $11 \mathrm{kyr}$ вP and the Pacific Water inflow may have contributed warm water to this site ${ }^{45}$. In the mid-late Holocene (8-0 kyr BP), RI-OH'-SST values were quite low and stable (Fig. 7a), reflecting expanded/seasonal sea-ice conditions in the mid-late Holocene (Fig. 7c).

Major sediment flux events at 13 and 11 kyr BP. Two distinct peaks at ca. 13 and $11 \mathrm{kyr}$ вP are found in the accumulation rates of terrigenous biomarkers, dinosterol, and bulk sediment (Fig. 7e, $\mathrm{f}$ and Supplementary Fig. 2). The first peak may reflect the YD flood event (cf. Ref. ${ }^{19}$ ) characterized by large amounts of terrigenous material and nutrients into the Beaufort Sea. Accumulation rates of terrigenous biomarkers $B$-sitosterol and campesterol as well as b-GDGTs started to increase at $12.83 \pm 0.15 \mathrm{kyr}$ BP (Fig. 7f, h), close to the onset of Beaufort Sea freshening (12.94 \pm $0.15 \mathrm{kyr}$ BP) estimated by Keigwin et al. ${ }^{19,58}$. The YD flood transported large amounts of heterogeneous sediments into the Beaufort Sea and resulted in increases in magnetic susceptibility, density, and (probably detrital ${ }^{59,60}$ ) $\mathrm{CaCO}_{3}$ contents (Fig. 5b-d). These sediments were most probably non-biogenic/organic and thus have caused a significant decrease of TOC content (Figs. 5e and $6 \mathrm{~g}$ and Supplementary Fig. 2). Such changes in physical and chemical properties occurred slightly before the YD flood, probably attributed to culminated meltwater production in the northwestern outlet area at the end of B/A.

In the earliest Holocene, an even stronger peak in terrigenous input occurred (Fig. 7f) at ca. $11 \mathrm{kyr}$ BP. High heterogeneous sediment flux resulted in similar characteristics as caused by the YD event (Fig. 5b-e). Although the second event is characterized by high sediment flux and coincides with the post-YD flood, its origin could not be unambiguously proven yet. The second event may have partially different sediment sources from the YD event (see "Discussion").

\section{Discussion}

Core site ARA04C/37 is particularly sensitive to changes in paleo sea-ice cover, because it is located in the area of modern seasonal sea-ice cover (Fig. 2). In contrast to a foraminifera-based study on the nearby Core 750 that proposed a permanent ice cover during the last deglaciation $(14-11.5 \mathrm{kyr} \mathrm{BP})^{61}$, the records of $\mathrm{PIP}_{25}$ and $\mathrm{RI}-\mathrm{OH}^{\prime}$-SST in Core ARA04C/37 clearly point to open-water conditions that allowed heat exchange with the atmosphere (Fig. 7a, c). Additionally, the minor differences of ${ }^{14} \mathrm{C}$ ages between planktic and benthic foraminifera (Supplementary Table 2) indicate that the surface and bottom water masses were relatively well ventilated, further corroborating the scenario of ice-free conditions during the last deglaciation. During the early Holocene, on the other hand, both the foraminifera study ${ }^{61}$ and our biomarker records (Fig. 7c) display more open-water conditions in comparison to the modern Beaufort Sea.

The Beaufort Sea itself is an oligotrophic system ${ }^{6}$ and the nutrient-rich Pacific Water inflow is an important nutrient source stimulating primary productivity. Studies (foraminifera, 
geochemical, and geophysical data) from sediment cores suggest an initial opening of Bering Strait at about $11.5 \mathrm{kyr} \mathrm{BP}^{46,62,63}$, whereas other evidence based on marine species dispersal suggests an earlier connection at about $13.3 \mathrm{kyr} \mathrm{BP}^{64-66}$. These contradictory evidences are recently reconciled by a gravitationally self-consistent sea-level simulation ${ }^{45}$. The authors predict the first opening of Bering Strait with shallow inundation at ca. 13 kyr BP. Substantial melting of the Cordilleran Ice Sheet and western Laurentide Ice Sheet (LIS) may have resulted in a local sea-level stillstand during 13-11.5 kyr BP, and then the total

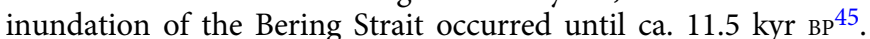
Primary production in our records remained relatively low during the deglacial to Holocene transition and generally increased from the early Holocene, except for two rapid increases triggered by high terrigenous input (Fig. 7e, f). It implies that even if the Bering Strait opened at $13 \mathrm{kyr}$ BP, probably because of its shallow inundation, the Pacific Water influence on primary production in the southern Beaufort Sea was small. Upon the total inundation of the Bering Strait at the early Holocene, primary production started to increase, reflecting more influence of Pacific Water inflow.

HBI-III has been proposed as an indicator for MIZ ${ }^{52-55}$. Among these studies, a study of surface sediments from the Barents Sea found that HBI-III maxima are correlated with the winter ice edge and thus proposed HBI-III as an indicator for winter $\mathrm{MIZ}^{53}$. This is challenged by a study from the East Greenland shelf where an enhancement of HBI-III was observed near the mid-July ice edge in an East Greenland fjord ${ }^{55}$. The difference in seasonality is controlled by the general sea-ice situations in both areas. Major parts of the Barents Sea are more or less ice free during late spring, summer, and autumn, and thus the ice edge is restricted to the cold/winter season. Along the East Greenland continental margin controlled by the East Greenland Current, on the other hand, sea ice is much more extended throughout the year and thus, the ice edge is more restricted to the summer season.

In our case, HBI-III production was enhanced twice during the Holocene (Fig. 7e). In the early Holocene, i.e., prior to the first HBI-III peak, it was nearly ice free throughout the year, reflected in very low $\mathrm{PIP}_{25}$ values $<0.2$ and variable SSTs (Fig. 7a, c). Then, a general trend toward an increasing sea-ice cover is coinciding with weakened insolation (Fig. 7c, j). Due to sea-ice expansion, the core site was first proximal to an MIZ situation during cold seasons, when HBI-III peaked at ca. $5.6 \mathrm{kyr}$ BP (Fig. 7e). The interval between the two HBI-III peaks (ca. 5-4 kyr вP) characterized by a clear decrease in HBI-III probably represents seasonal sea-ice conditions. As sea ice further expanded, the second period of MIZ may have existed during warm seasons at ca. 3.5 kyr BP, shown by peaked HBI-III (Fig. 7e). During the last 2.5 kyrs, reduced HBI-III and dinosterol production (Figs. 6b, $\mathrm{c}$ and 7e) implies a more extended ice cover. Sea-ice variability is illustrated in Fig. 8.

A novel proxy $\mathrm{HBI} \mathrm{TR}_{25}$ shows strong associations with the satellite-derived spring chlorophyll $a$ concentration in the Barents Sea, and thus has been proposed as a spring phytoplankton bloom proxy ${ }^{67}$. Although the proxy is restricted to a regional area, the $\mathrm{HBI} \mathrm{TR}_{25}$ determined in Core ARA04C/37 seems to support our reconstruction of the MIZ history and by this the applicability of the proxy. Higher values of $\mathrm{HBI} \mathrm{TR}_{25}$ may point to enhanced occurrence of spring blooms between 8 and $5 \mathrm{kyr}$ BP, indicating that the core site was relatively ice free in spring. Hence, a winter MIZ may have existed at certain times within this period. On the other hand, lower values of $\mathrm{HBI} \mathrm{TR}_{25}$ may suggest reduced numbers of spring blooms from $5.6 \mathrm{kyr}$ вP to present. One of the explanations is the existence of a spring sea-ice cover, which may have limited the spring blooms. This coincides with the expanding sea-ice cover and longer sea-ice duration during this time interval. To some extent, a summer MIZ may have existed occasionally within this period. These scenarios are in agreement with the HBI-III record, suggesting that the core site was probably close to a winter MIZ at ca. $5.6 \mathrm{kyr}$ BP and to a summer MIZ at ca. 3.5 kyr BP.

The changes in RI-OH'-SST values seem to correlate with changes in sea-ice concentrations. That means quite high but variable temperatures occurred during dominantly ice-free periods, while low but stable temperatures during ice-covered periods (Fig. 7a, c), suggesting the proxy's potential as a tool for temperature reconstruction in the Arctic Ocean. To our knowledge, the RI-OH'-SST proxy was first studied on surface sediments from the Chinese coastal seas and the Yangtze Estuary, and then a global surface sediment compilation was assessed ${ }^{32}$. Samples from northern high latitudes are mainly collected from the Fram Strait $^{68}$. In these samples, residual SSTs derived from RI-OH'-SST minus remote sensing SST are relatively small but generally above zero. Therefore, the absolute values should still be interpreted with caution. Nevertheless, based on the close association between the RI-OH'-SSTs and the sea-ice concentrations, we propose that the proxy most likely reflects winter/spring SSTs in the southern Beaufort Sea. Low and stable SSTs during the seasonal sea-ice periods (mid-late Holocene) (Fig. 7a, c) suggest that $\mathrm{RI}-\mathrm{OH}^{\prime}$ may record SST in the ice-covered seasons, likely in winter. As insolation declined in the mid-late Holocene, icecovered seasons might have prolonged and persisted into early spring.

Superimposed on the long-term changes in sea ice, primary production, terrestrial input, MIZ and SST are two extremely high sediment flux events during the deglacial to Holocene transition (at ca. 13 and $11 \mathrm{kyr} \mathrm{BP}$ ), which are related to the YD flood and the post-YD flood events.

The YD cooling event (12.9-11.7 kyr вP) was the longest interruption to the gradual climate warming since the severe Last Glacial Maximum (Fig. 7j). Meltwater of LIS draining through the Arctic Ocean to the Nordic seas has been suggested to have profound impacts on slowing down the AMOC and triggering the YD cooling ${ }^{17,22}$. Glacial system modeling, and seismic reflection data as well as physical properties from the Beaufort slope, shows massive floods possibly via a northwestern outlet into the Arctic Ocean at the onset of the YD (Fig. 3) 22,69 . Recently, Keigwin et al. ${ }^{19}$ provided initial freshening evidence of the southern Beaufort Sea. Core JPC15 recorded the freshening in a decrease of $\delta^{18} \mathrm{O}$ values of the planktic foraminifera Neogloboquadrina pachyderma by at least $1 \%$ at the start of the YD (Fig. 7i). In a pilot work, paleosalinity reconstruction from $\delta^{2} \mathrm{H}$ of palmitic acid in the same region (Core PS72/291-2; Fig. 1) shows a significant reduction of salinity directly prior to the $\mathrm{YD}^{70}$. Other evidence, e.g., decreased $\delta^{18} \mathrm{O}$ values of planktic foraminifera found in the Laptev Sea, Yermak Plateau, Amundsen Basin, and Mendeleev Ridge $^{71-74}$, a prominent increase in sea-ice cover in the Laptev Sea continental margin ${ }^{35}$, and a pulse in detrital dolomitic limestones (Arctic-Canadian sediment source) in the central Arctic Ocean ${ }^{59}$, point to a YD-age Arctic freshening sourced from the LIS (Fig. 3$)^{75}$.

Meltwater production from the northwestern sector of the LIS might be a component causing the Beaufort Sea freshening. Model simulation suggests that runoff to the Arctic Ocean from melting Keewatin Dome alone was sufficient to slow down the AMOC during $\mathrm{YD}^{22}$. Thus, it is possible that such melting culminated at the end of the $\mathrm{B} / \mathrm{A}$ and strengthened freshening. This is supported by changes in physical properties of Core ARA04C/ 37 that slightly predated YD (Fig. 5). Another possible freshwater component is the outburst from proglacial/subglacial lakes, such as Lake Agassiz. Our multiple biomarker records also document 


\section{Sea ice trend}

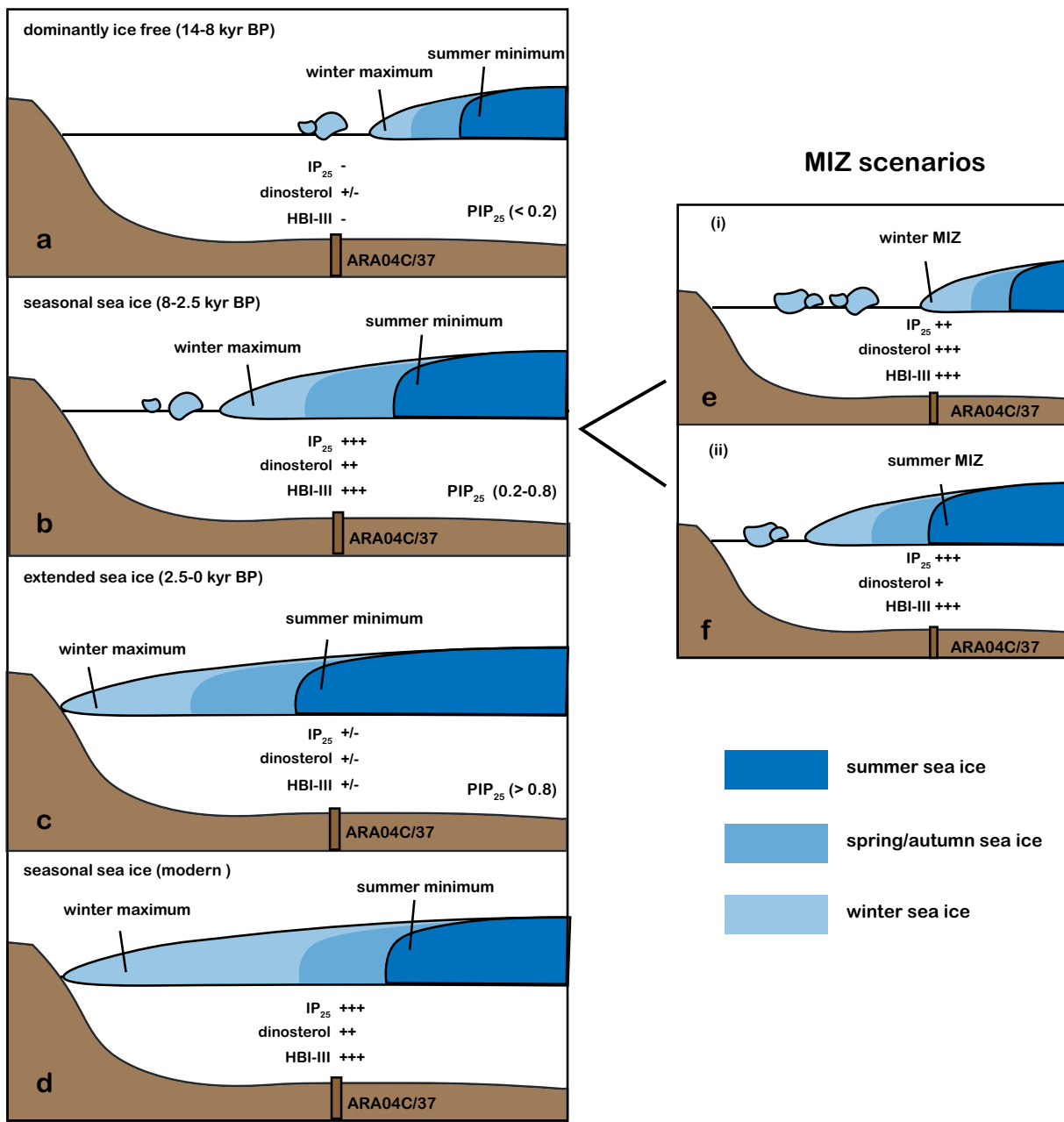

Fig. 8 Schematic illustration of sea-ice variability in the southern Beaufort Sea. a-c Paleo sea-ice variability based on PIP 25 record, $\mathbf{d}$ modern sea-ice conditions according to sea-ice concentrations from 1988 to 2007 (see Fig. 2). e-f Show the winter and summer MIZ conditions of seasonal sea ice.

this $\mathrm{YD}$ event and suggest the freshening was more related to a flood event as outlined in the following (Figs. 5 and 7).

B-GDGTs are synthesized by bacteria and can be found in numerous terrestrial settings, e.g., soils, lakes, and rivers ${ }^{37-40}$. As freshly deglaciated surfaces probably have negligible soil organic matter, the increases of b-GDGTs at the onset of the YD does likely not indicate input from soils. On the other hand, increase of meltwater in the rivers would not increase b-GDGTs production. Hence the main contribution of b-GDGTs increases seems not from the rivers. Another possible source could be from the melting ice sheet, i.e., b-GDGTs might have been entrained into the base of the ice sheet when it glaciated and were released when it deglaciated. However, such release and accumulation of bGDGTs should be continuous processes. The sharp increase and peak accumulation of b-GDGTs at the start of the YD (Fig. 7h) point to lakes as the most probable source. In such lakes bGDGTs could have been accumulated in a relatively stable environment for a long time and then been delivered to the Beaufort Sea within a short period.

This interpretation is supported by the riverine input proxy $\mathrm{F}_{\mathrm{C} 32} 1,15$ (fractional abundance of $\mathrm{C}_{32}$ 1,15-diol). The $\mathrm{C}_{32} 1,15-$ diol is found particularly abundant in freshwater systems ${ }^{41}$, and its production has been related to flow regimes ${ }^{76}$. A study from the Amazon River shows that the highest abundance of $\mathrm{C}_{32}$ 1,15diol exists in water bodies with low flow velocity and low turbidity, while the lowest abundance of $\mathrm{C}_{32}$ 1,15-diol is found in conditions with high turbidity and high flow velocity ${ }^{76}$. This suggests that a high-velocity flow regime like a flood producing higher turbidity would limit the $\mathrm{C}_{32}$ 1,15-diol production. Thus, the significant drop in $\mathrm{F}_{\mathrm{C} 321,15}$ values during the $\mathrm{YD}$ (Fig. $7 \mathrm{~g}$ ) characterizes a flood event of high erosive power and high flow velocity in turbid waters.

Assuming that the high-resolution terrestrial records of Core ARA04C/37 represent the YD flood event, a duration was estimated based on records of terrigenous sterols and b-GDGTs (Figs. 6d and $7 \mathrm{~h}$ ). The peak discharge started at $12.78 \pm 0.15 \mathrm{kyr}$ BP and ended up at $12.63 \pm 0.13 \mathrm{kyr}$ BP, resulting in a flood duration of about 150 years. Such estimate is close to the duration of 130 years estimated by Keigwin et al. ${ }^{19}$.

Although our terrestrial biomarker records in combination with previous paleosalinity reconstructions ${ }^{19,70}$ indicate a strong YD flood, the flood water source still remains unclear. Coinciding with the YD event, a large lake-level drop of Lake Agassiz (with an estimated freshwater release of $\sim 17,000 \mathrm{~km}^{3}$; Ref. ${ }^{77}$ ) has been proposed as the freshwater source ${ }^{23}$. According to more recent studies, however, no clear field evidence (ice margins or shorelines) supports that Lake Agassiz drained to any northwestern outlet before $10.8-10.1 \mathrm{kyr} \mathrm{BP}^{21,24}$. It cannot be excluded that the northwestern outlet of Lake Agassiz opened at an earlier phase and its evidence has been removed by a readvance of LIS. 
Otherwise the flood may have other water sources, e.g., outburst from further northern proglacial/subglacial lakes. If so, the freshwater discharge from these lakes alone was too small to trigger the YD cooling. Besides freshening in the Beaufort Sea, input of freshwater during the YD was also found in the Northeast Pacific sea (Ref. ${ }^{78}$ and references therein). A recent model simulation suggests that if the Bering Strait partially opened at the start of $\mathrm{YD}^{45}$, some of the freshwater from the Northeast Pacific could be transported through the Arctic Ocean to the Nordic seas, contributing to a collapse of the $\mathrm{AMOC}^{78}$.

In the earliest Holocene, following the YD flood, a post-YD flood at ca. $11.3 \mathrm{kyr}$ вр has been identified by field data from the Fort McMurray area, and the freshwater source is suggested to derive from proglacial lakes McMurray, Meadow, and Churchill $^{24}$. Evidence in the Fort McMurray region is in line with field data from the Mackenzie Delta supporting that a second highenergy fluvial episode occurred in the delta between 11.7 and 9.3 $\mathrm{kyr} \mathrm{BP}^{23}$. More recently, seismic and geophysical data from the Beaufort margin also indicate that the second event probably initiated at ca. $11.3 \mathrm{kyr}^{6}{ }^{69}$. The timing of the second flood coincides with the $\mathrm{PBO}$, thus it has been proposed that the second flood may have triggered the $\mathrm{PBO}^{25,69}$. As a large amount of freshwater from the Baltic Ice Lake entered the Arctic marginally predating the $\mathrm{PBO}^{79}$, Klotsko et al. ${ }^{69}$ regarded the second flood injection as a tipping point for sufficient weakening of the AMOC during the $\mathrm{PBO}$.

Despite the field data indicate a second flood, direct evidence for freshwater input is still missing from the marine records. The $\delta^{18} \mathrm{O}$ record of Core JPC15 shows minimum values only during the YD flood, whereas values were even higher than the $2 \%$ baseline during the second event (Fig. 7i) ${ }^{19}$. A similar case was described for a piston core from the Mackenzie Trough, where a coarse-layered unit was dated to $11.5-11.3 \mathrm{kyr} \mathrm{BP}^{80}$, while the very positive $\delta^{18} \mathrm{O}$ values $(\sim 2.7-3.5 \%)$ argued against the hypothesis of an outburst from proglacial lakes. So far, the only freshwater evidence is found in Core P189AR-P45 (see Fig. 1 for location), showing a drop of $\delta^{18} \mathrm{O}$ values at ca. $11.5 \mathrm{kyr} \mathrm{BP}^{81}$. However, since the age-depth model of this core is not well constrained ${ }^{81}$, the timing of the freshwater signal might be shifted to the YD period when improving the age model. In comparison to the YD flood, biomarker records also show slight differences during the second event (Fig. $7 \mathrm{~g}, \mathrm{~h}$ ). Moderate values of $\mathrm{F}_{\mathrm{C} 32} 1,15$ during the second event indicate relatively stable flow regimes and smaller discharge than the YD flood (Fig. 7g). Otherwise extremely high flow velocity would limit $\mathrm{C}_{32}$ 1,15-diol production. Accumulation of bGDGTs was also much smaller than during the YD (Fig. 7h), and seems to have different sources. This evidence gives rise to the question whether the high sediment flux was caused by a flood or whether it was controlled by other processes.

In this context, one should keep in mind that the second event also coincided with global meltwater pulse 1B (MWP 1B). Recent studies in the Okhotsk Sea and Pacific Beringia provided direct evidence of coastal erosion induced by the rapid sea-level rise ${ }^{82,83}$. In these records, two distinct maxima of terrigenous material were observed within the rapid sea-level rise at ca. 14 and $11 \mathrm{kyr}$ вр (MWP 1A and 1B). In the Kara Sea, high terrigenous sediment fluxes characterized by significantly increased $\mathrm{C} / \mathrm{N}$ ratios and refractory organic matter were recorded at about $11 \mathrm{kyr}$ вр and also related to increased coastal erosion due to the postglacial flooding of the shelf sea ${ }^{84,85}$. In the Labrador Sea, a high sedimentation layer containing increased detrital carbonates was dated to ca. 11.5-11.3 $\mathrm{kyr} \mathrm{BP}^{86}$. Although the authors related it to "Heinrich event 0 ," almost simultaneous signals widely found in the Arctic may support the interpretation of sea-level rise induced coastal erosion. It is therefore possible that the high sediment flux during the second event was partially caused by coastal erosion and subsequent deposition of the eroded terrigenous material.

Although field data indicate a second flood during the early Holocene, marine evidence suggests that the high sediment flux could be caused by a meltwater flood and/or shelf flooding induced coastal erosion. Further work, e.g., comprehensive proxy reconstruction of freshwater discharge and paleosalinity (cf. Ref. ${ }^{70}$ ) as well as carbon source constraint (cf. Ref. ${ }^{82}$ ), is hence needed to distinguish different processes.

\section{Methods}

Chronology. Radiocarbon dates of Core ARA04C/37 and JPC15 are consistent during the last deglaciation (Fig. 4). A red vertical line is placed close to the onset of the magnetic susceptibility rise (Fig. 5a, b), and the almost same ${ }^{14} \mathrm{C}$ ages from both cores at the vertical line suggest a good age constraint of the onset of magnetic susceptibility change. ${ }^{14} \mathrm{C}$ dates from the two cores are highly consistent below 400 cmbsf (Fig. 4a). However, age offsets are enlarged from near $350 \mathrm{cmbsf}$ toward the core top (Fig. 4a), indicating a weakened correlation between Core ARA04C/37 and JPC15. Therefore, we established the age-depth model for core ARA04C/37 by including six $\mathrm{AMS}^{14} \mathrm{C}$ dates from Core JPC15 below $400 \mathrm{cmbsf}$ (Supplementary Table 1). Paired dating shows a mean difference of around 200 years between planktic and benthic foraminifera (Supplementary Table 2). Considerable ventilation allows mixed species (planktic and benthic) being used for age constraints. As discussed in detail by Keigwin et al. ${ }^{19}, \Delta R$ was defined as $200 \pm 100$ years in YD and $0 \pm 100$ in the Holocene and B/A in the age model. The age-depth model was developed using the "Bacon" software of Blaauw and Christen ${ }^{87}$. Bulk sediments of the top $\mathrm{cm}$ of the core were analyzed by gamma spectrometry (HPGe planar detector). Based on excess ${ }^{210} \mathrm{~Pb}$ in the uppermost centimeters and detectable anthropogenic ${ }^{137} \mathrm{Cs}$ in the top sample, surface sediments were identified to be modern, therefore, the core top was fixed to $0 \mathrm{kyr}$ вр. Between 450 and $500 \mathrm{cmbsf}$ (unit 1 ), ${ }^{14} \mathrm{C}$ dates are constant (mean ${ }^{14} \mathrm{C}$ age of 11,160 years) and are indicative for event 1 (Fig. 4a). Although the onset of event 1 is well constrained, because there is no clear termination of event 1 shown in magnetic susceptibility, the range of unit 1 is less constrained. This might lead to an over- or underestimate of sedimentation rate. Similarly, despite that magnetic susceptibility in both cores shows generally synchronous changes between 375 and $420 \mathrm{cmbsf}$ (Fig. 5a, b), enlarged age offsets indicate a weaker correlation between the two cores (Fig. 4a and Supplementary Table 1). Therefore, we define the unit 2 (event 2) mainly based on four constant ${ }^{14} \mathrm{C}$ dates (mean ${ }^{14} \mathrm{C}$ age of 9750 years) between 295 and 375 cmbsf, with poor constraints in both onset and termination of the event. The second high sedimentation unit (295-375 cmbsf) may be thicker than shown by the four dates, therefore we kept the four dates for more precise age model constraints, even though the last date of the plateau is not strictly increasing (Fig. 4). A "boundary" function was applied in the two units, which may have experienced distinctively high sedimentation rates (cf. Ref. ${ }^{88}$ ). All the ${ }^{14} \mathrm{C}$ ages were transformed into calendar ages following Reimer et al. ${ }^{89}$ via the Marine13 curve.

Bulk parameters. For organic geochemical analyses, sediment samples were freeze-dried, grounded, and homogenized. TOC contents were determined by a Carbon-Sulfur Analyser (CS-125, Leco) after decarbonization with hydrochloric acids. Total carbon (TC) contents were analyzed by a Carbon-Nitrogen-Sulfur Analyser (Elementar III, Vario), and used for calculation of carbonate contents $\left(\mathrm{CaCO}_{3}=(\mathrm{TC}-\mathrm{TOC}) \times 8.333\right)$. Carbon isotope composition of organic matter $\left(\delta^{13} \mathrm{C}_{\text {org }}\right)$ was analyzed by means of a Thermo Delta V Isotope Ratio Mass Spectrometer connected to a Thermo Flash $2000 \mathrm{CHNS} / \mathrm{OH}$ Elemental Analyzer employing continuous flow, performed at the Korea Polar Research Institute. $\delta^{13} \mathrm{C}_{\text {org }}$ values are given in per mil notation relative to Vienna Pee Dee Belemnite International Standard. Reference gases were calibrated relative to Indiana University Acetanilide\#1, USGS40, Urea, and Thermo Soil standards. For a randomly selected set of samples, duplicate analyses were carried out to determine the analytical error. Analytical precision is within $0.2 \%$.

Biomarker analyses. Freeze-dried sediments ( $5 \mathrm{~g}$ ) were ultrasonically extracted with DCM:MeOH $(2: 1, \mathrm{v} / \mathrm{v})$, and internal standards $(0.076 \mu \mathrm{g}$ 7-hexylnonadecane (7-HND) and $10.7 \mu \mathrm{g} 5 \alpha$-androstan-3 $\beta$-ol (androstanol)) were added prior to analytical treatment. Total lipid extracts were concentrated and separated via open column chromatography with silica gel $(6 \mathrm{~mm}$ i.d. $* 4.5 \mathrm{~cm})$. The lipids were eluted by $5 \mathrm{ml} n$-hexane for hydrocarbon fraction, followed by $9 \mathrm{ml}$ ethyl acetate: $n$-hexane $(1: 4 \mathrm{v} / \mathrm{v})$ for sterol fraction (containing diols). The sterol fraction was further derivatized with $200 \mu \mathrm{l}$ bis-trimethylsilyl-trifluoracet-amide $\left(60^{\circ} \mathrm{C}, 2 \mathrm{~h}\right)$. The composition of the hydrocarbons, sterols, and diols was analyzed by gas chromatography (GC)-mass spectrometry (MS) (Agilent 7890GC-Agilent 5977 A). Compounds were identified by comparison of GC retention times with published mass spectra (highly branched isoprenoids/HBIs: Refs. ${ }^{28,90}$; sterols: Refs. ${ }^{33,91}$; diols: Refs. ${ }^{92,93}$ ).

For quantification of HBIs, their molecular ions $\left(\mathrm{m} / z 350\right.$ for $\mathrm{IP}_{25}, \mathrm{~m} / z 348$ for HBI II, and $m / z 346$ for HBI-III) were used in relation to the fragment ion $\mathrm{m} / z 266$ 
(internal standard 7-HND). The sterols, brassicasterol (24-methylcholesta-5,22E-

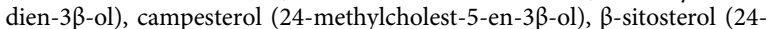

ethylcholest-5-en-3 $\beta$-ol), and dinosterol $(4 \alpha, 23,24 \mathrm{R}$-trimethyl-5 $\alpha$-cholest-22E-en$3 \beta$-ol) were quantified as trimethylsilyl ethers. Their molecular ions $\mathrm{m} / \mathrm{z} 470, \mathrm{~m} / \mathrm{z}$ $472, \mathrm{~m} / z 486$, and $\mathrm{m} / \mathrm{z} 500$ were used in relation to the molecular ion $\mathrm{m} / \mathrm{z} 348$ of androstanol. External calibration curves (cf. Ref. ${ }^{35}$ ) were applied and specific response factors were calculated for these ions. For quantification of the relative abundance of the diols, the fragment ions $\mathrm{m} / z 313.3\left(\mathrm{C}_{28}\right.$ 1,13-diol, $\mathrm{C}_{30}$ 1,15-diol) and $341.3\left(\mathrm{C}_{30}\right.$ 1,13-diol, $\mathrm{C}_{32}$ 1,15-diol $)$ were used.

Reconstruction of sea-ice concentrations ( $\mathrm{PIP}_{25}$ ) followed Müller et al. (the following equation $)^{30}$ :

$$
\mathrm{PIP}_{25}=\left[\mathrm{IP}_{25}\right] /\left(\left[\mathrm{IP}_{25}\right]+[\text { Phytoplankton biomarker }] \times c\right)
$$

with balance factor $c=$ mean $\mathrm{IP}_{25}$ concentration/mean phytoplankton biomarker concentration.

Due to a presumed terrestrial origin of brassicasterol in this region (see "Results"), the calculation of PIP $_{25}$ was based on the pelagic algal biomarkers dinosterol.

The tri-unsaturated HBI biomarkers (triene, Z- and E-isomer) are commonly found in marine sediment. Based on studies in the Barents Sea, HBI-III (Z) producers favor nutrient-rich and stratified upper water column at the ice edge ${ }^{53}$. For simplification, the term "HBI-III" is used in the main text, representing the "HBI-III (Z)." The relationship between the relative proportions of HBI-III (Z) and HBI-III (E) and spring chl $a$ in surface sediment from the western Barents Sea suggests the potential of a novel $\mathrm{HBI}$ proxy $\left(\mathrm{HBI} \mathrm{TR}_{25}\right)$ indicating the spring phytoplankton bloom (the following equation) ${ }^{67}$ :

$$
\mathrm{HBITR} \mathrm{T}_{25}=[\mathrm{Z}-\text { triene }] /([\mathrm{Z}-\text { triene }]+[\mathrm{E}-\text { triene }]) .
$$

$\mathrm{F}_{\mathrm{C} 321,15}$ (fractional abundances of $\mathrm{C}_{32}$ 1,15-diol) indicative for aquatic riverine input was calculated based on the following equation ${ }^{44}$ :

$\mathrm{F}_{\mathrm{C} 321,15}=\left[\mathrm{C}_{32} 1,15\right] /\left(\left[\mathrm{C}_{32} 1,15\right]+\left[\mathrm{C}_{30} 1,15\right]+\left[\mathrm{C}_{30} 1,13\right]+\left[\mathrm{C}_{28} 1,13\right]\right)$.

For GDGT analyses, $5 \mathrm{~g}$ sediment was ultrasonically extracted with DCM: $\mathrm{MeOH}(2: 1 \mathrm{v} / \mathrm{v})$, and internal standard $\left(\mathrm{C}_{46}-\mathrm{GDGT}, 1 \mu \mathrm{g}\right.$ per sample) was added prior to analytical treatment. The GDGT fraction was separated from other fractions via open column chromatography and eluted with $5 \mathrm{ml}$ DCM:MeOH (1:1 $\mathrm{v} / \mathrm{v})$, dried and re-dissolved in hexane:isopropanol $(99: 1 \mathrm{v} / \mathrm{v})$, and then filtered via a polytetrafluoroethylene filter with a pore size of $0.45 \mu \mathrm{m}$. Compound identification and quantification were carried out by a high-performance liquid chromatography/ atmospheric pressure chemical ionization-MS according to the method described by Meyer et al. ${ }^{83}$. The MS-detector was set for SIM of the following $(\mathrm{M}+\mathrm{H})^{+}$ions: m/z 1300.3 (OH-GDGT-0), 1298.3 (OH-GDGT-1), 1296.3 (OH-GDGT-2), 1050 (GDGT-IIIa/IIIa'), 1036 (GDGT-IIa/IIa'), 1022 (GDGT-Ia), and $744\left(\mathrm{C}_{46}\right.$ standard), with a dwell time of $57 \mathrm{~ms}$ per ion.

Calculation of ring index of hydroxylated tetraethers $\left(\mathrm{RI}-\mathrm{OH}^{\prime}\right)$ and its derived SST follows Lü et al. (the following equations) ${ }^{32}$ :

$$
\begin{gathered}
\mathrm{RI}-\mathrm{OH}^{\prime}=([\mathrm{OH}-\mathrm{GDGT}-1]+2 \times[\mathrm{OH}-\mathrm{GDGT}-2]) \\
/([\mathrm{OH}-\mathrm{GDGT}-0]+[\mathrm{OH}-\mathrm{GDGT}-1]+[\mathrm{OH}-\mathrm{GDGT}-2]), \\
\mathrm{RI}-\mathrm{OH}^{\prime}=0.0382 \times \mathrm{SST}+0.1 .
\end{gathered}
$$

Accumulation rates. Accumulation rates of bulk sediment, bulk organic carbon, $\mathrm{CaCO}_{3}$, and biomarkers are calculated by using the following equations (cf. Ref. ${ }^{94}$ ):

$$
\text { BulkAR }=\mathrm{SR} \times(\mathrm{WBD}-1.026 \times \mathrm{PO}),
$$

$$
\mathrm{TOC}\left(/ \mathrm{CaCO}_{3} / \mathrm{BM}\right) \mathrm{AR}=\text { BulkAR } \times \mathrm{TOC}\left(/ \mathrm{CaCO}_{3} / \mathrm{BM}\right),
$$

BulkAR $=$ bulk sediment accumulation rate $\left(\mathrm{g} \mathrm{cm}^{-2} \mathrm{kyr}^{-1}\right)$; $\mathrm{SR}=$ sedimentation rate $\left(\mathrm{cm} \mathrm{kyr}^{-1}\right)$; WBD = wet bulk density $\left(\mathrm{g} \mathrm{cm}^{-3}\right) ; \mathrm{PO}=$ porosity $(\%)$; TOCAR $=$ total organic carbon accumulation rate $\left(\mathrm{g} \mathrm{cm}^{-2} \mathrm{kyr}^{-1}\right) ; \mathrm{CaCO}_{3} \mathrm{AR}=$ carbonate accumulation rate $\left(\mathrm{g} \mathrm{cm}^{-2} \mathrm{kyr}^{-1}\right) ; \mathrm{BM}=$ biomarker concentration $\left(\mu \mathrm{g} \mathrm{g}^{-1} \mathrm{Sed}\right)$; and $\mathrm{BMAR}=$ biomarker accumulation rate $\left(\mu \mathrm{g} \mathrm{cm}^{-2} \mathrm{kyr}^{-1}\right)$.

\section{Data availability}

The data sets generated during and analyzed during the current study are available in PANGAEA repository (https://doi.org/10.1594/PANGAEA.915048) ${ }^{95}$.

Received: 23 March 2020; Accepted: 15 September 2020;

Published online: 09 October 2020

\section{References}

1. Serreze, M. C., Holland, M. M. \& Stroeve, J. Perspectives on the Arctic's shrinking sea-ice cover. Science 315, 1533-1536 (2007).
2. Screen, J. A. \& Simmonds, I. The central role of diminishing sea ice in recent Arctic temperature amplification. Nature 464, 1334-1337 (2010).

3. Dai, A., Luo, D., Song, M. \& Liu, J. Arctic amplification is caused by sea-ice loss under increasing CO2. Nat. Commun. 10, 121-133 (2019).

4. Kim, K. et al. Vertical feedback mechanism of winter Arctic amplification and sea ice loss. Sci. Rep. 9, 1184 (2019).

5. Loeb, V. et al. Effects of sea-ice extent and krill or salp dominance on the Antarctic food web. Nature 387, 897-900 (1997).

6. Mundy, C. J. et al. Contribution of under-ice primary production to an iceedge upwelling phytoplankton bloom in the Canadian Beaufort Sea. Geophys. Res. Lett. 36, L17601 (2009).

7. Sévellec, F., Fedorov, A. V. \& Liu, W. Arctic sea-ice decline weakens the Atlantic Meridional Overturning Circulation. Nat. Clim. Chang. 7, 604-610 (2017).

8. Stroeve, J., Holland, M. M., Meier, W., Scambos, T. \& Serreze, M. Arctic sea ice decline: faster than forecast. Geophys. Res. Lett. 34, L09501 (2007).

9. Routson, C. C. et al. Mid-latitude net precipitation decreased with Arctic warming during the Holocene. Nature 568, 83-87 (2019).

10. Parkinson, C. L. \& Cavalieri, D. J. Arctic sea ice variability and trends, 1979-2006. J. Geophys. Res. 113, C07003 (2008).

11. Stroeve, J. C. et al. Trends in Arctic sea ice extent from CMIP5, CMIP3 and observations. Geophys. Res. Lett. 39, L16502 (2012).

12. Matsumura, S. \& Kosaka, Y. Arctic-Eurasian climate linkage induced by tropical ocean variability. Nat. Commun. 10, 1-8 (2019).

13. Kaufman, D. S. et al. Holocene thermal maximum in the western Arctic (0$180^{\circ}$ W). Quat. Sci. Rev. 23, 529-560 (2004).

14. Holmes, R. M. et al. A circumpolar perspective on fluvial sediment flux to the Arctic ocean. Global Biogeochem. Cycles 16, 1098 (2002).

15. Duk-Rodkin, A. \& Hughes, O. L. Tertiary-quaternary drainage of the preglacial Mackenzie basin. Quat. Int. 22-23, 221-241 (1994).

16. McManus, J. F., Francois, R., Gherardl, J. M., Keigwin, L. \& Drown-Leger, S. Collapse and rapid resumption of Atlantic meridional circulation linked to deglacial climate changes. Nature 428, 834-837 (2004).

17. Peltier, W. R., Vettoretti, G. \& Stastna, M. Atlantic meridional overturning and climate response to Arctic Ocean freshening. Geophys. Res. Lett. 33, L06713 (2006).

18. Broecker, W. S. et al. Routing of meltwater from the Laurentide Ice Sheet during the Younger Dryas cold episode. Nature 341, 318-321 (1989).

19. Keigwin, L. D. et al. Deglacial floods in the Beaufort Sea preceded Younger Dryas cooling. Nat. Geosci. 11, 599-604 (2018).

20. Leydet, D. J. et al. Opening of glacial Lake Agassiz's eastern outlets by the start of the Younger Dryas cold period. Geology 46, 155-158 (2018).

21. Fisher, T. G. \& Lowell, T. V. Testing northwest drainage from Lake Agassiz using extant ice margin and strandline data. Quat. Int. 260, 106-114 (2012).

22. Tarasov, L. \& Peltier, W. R. Arctic freshwater forcing of the Younger Dryas cold reversal. Nature 435, 662-665 (2005).

23. Murton, J. B., Bateman, M. D., Dallimore, S. R., Teller, J. T. \& Yang, Z. Identification of Younger Dryas outburst flood path from Lake Agassiz to the Arctic Ocean. Nature 464, 740-743 (2010).

24. Fisher, T. G., Waterson, N., Lowell, T. V. \& Hajdas, I. Deglaciation ages and meltwater routing in the Fort McMurray region, northeastern Alberta and northwestern Saskatchewan, Canada. Quat. Sci. Rev. 28, 1608-1624 (2009).

25. Fisher, T. G., Smith, D. G. \& Andrews, J. T. Preboreal oscillation caused by a glacial Lake Agassiz flood. Quat. Sci. Rev. 21, 873-878 (2002).

26. Jin, Y. K. ARA04C cruise report: barrow, US-Beaufort Sea, CAN-Nome, US 6-24 September 2013 (Korea Polar Research Institute, Incheon, 2013).

27. Gamboa, A., Montero-Serrano, J. -C., St-Onge, G., Rochon, A. \& Desiage, P. -A. Mineralogical, geochemical, and magnetic signatures of surface sediments from the Canadian Beaufort Shelf and Amundsen Gulf (Canadian Arctic). Geochem. Geophys. Geosyst. 18, 488-512 (2017).

28. Belt, S. T. et al. A novel chemical fossil of palaeo sea ice: IP25. Org. Geochem. 38, 16-27 (2007).

29. Brown, T. A., Belt, S. T., Tatarek, A. \& Mundy, C. J. Source identification of the Arctic sea ice proxy IP 25. Nat. Commun. 5, 4197 (2014).

30. Müller, J. et al. Towards quantitative sea ice reconstructions in the northern North Atlantic: a combined biomarker and numerical modelling approach. Earth Planet. Sci. Lett. 306, 137-148 (2011).

31. Smik, L., Cabedo-Sanz, P. \& Belt, S. T. Semi-quantitative estimates of paleo Arctic sea ice concentration based on source-specific highly branched isoprenoid alkenes: A further development of the PIP25 index. Org. Geochem. 92, 63-69 (2016).

32. Lü, X. et al. Hydroxylated isoprenoid GDGTs in Chinese coastal seas and their potential as a paleotemperature proxy for mid-to-low latitude marginal seas. Org. Geochem. 89, 31-43 (2015).

33. Volkman, J. K. A review of sterol markers for marine and terrigenous organic matter. Org. Geochem. 9, 83-99 (1986). 
34. Fahl, K. \& Stein, R. Biomarkers as organic-carbon-source and environmental indicators in the late quaternary Arctic Ocean: problems and perspectives. Mar. Chem. 63, 293-309 (1999).

35. Fahl, K. \& Stein, R. Modern seasonal variability and deglacial/Holocene change of central Arctic Ocean sea-ice cover: new insights from biomarker proxy records. Earth Planet. Sci. Lett. 351, 123-133 (2012).

36. Rampen, S. W., Abbas, B. A., Schouten, S. \& Damsté, J. S. S. A comprehensive study of sterols in marine diatoms (Bacillariophyta): implications for their use as tracers for diatom productivity. Limnol. Oceanogr. 55, 91-105 (2010).

37. Hopmans, E. C. et al. A novel proxy for terrestrial organic matter in sediments based on branched and isoprenoid tetraether lipids. Earth Planet. Sci. Lett. 224, 107-116 (2004).

38. Weijers, J. W. H., Schouten, S., van den Donker, J. C., Hopmans, E. C. \& Sinninghe Damsté, J. S. Environmental controls on bacterial tetraether membrane lipid distribution in soils. Geochim. Cosmochim. Acta 71, 703-713 (2007).

39. Blaga, C. I. et al. Branched glycerol dialkyl glycerol tetraethers in lake sediments: can they be used as temperature and $\mathrm{pH}$ proxies? Org. Geochem. 41, 1225-1234 (2010).

40. De Jonge, C. et al. In situ produced branched glycerol dialkyl glycerol tetraethers in suspended particulate matter from the Yenisei River, Eastern Siberia. Geochim. Cosmochim. Acta 125, 476-491 (2014).

41. Zhang, Z., Metzger, P. \& Sachs, J. P. Co-occurrence of long chain diols, ketools, hydroxy acids and keto acids in recent sediments of Lake El Junco, Galápagos Islands. Org. Geochem. 42, 823-837 (2011).

42. de Bar, M. W. et al. Constraints on the application of long chain diol proxies in the Iberian Atlantic margin. Org. Geochem. 101, 184-195 (2016).

43. Lattaud, J. et al. The C32 alkane-1,15-diol as a proxy of late Quaternary riverine input in coastal margins. Clim. Past 13, 1049-1061 (2017).

44. Lattaud, J. et al. The C32 alkane-1,15-diol as a tracer for riverine input in coastal seas. Geochim. Cosmochim. Acta 202, 146-158 (2017).

45. Pico, T., Mitrovica, J. X. \& Mix, A. C. Sea level fingerprinting of the Bering Strait flooding history detects the source of the Younger Dryas climate event. Sci. Adv. 6, eaay2935 (2020).

46. Jakobsson, M. et al. Post-glacial flooding of the Bering Land Bridge dated to 11 cal ka BP based on new geophysical and sediment records. Clim. Past 13, 991-1005 (2017).

47. Laskar, J. et al. A long-term numerical solution for the insolation quantities of the Earth. Astron. Astrophys. 428, 261-285 (2004).

48. Niebauer, H. J. \& Alexander, V. Oceanographic frontal structure and biological production at an ice edge. Cont. Shelf Res. 4, 367-388 (1985).

49. Smith, W. O. \& Nelson, D. M. Phytoplankton bloom produced by a receding ice edge in the Ross Sea: spatial coherence with the density field. Science. 227, 163-166 (1985).

50. Ackley, S. F. \& Sullivan, C. W. Physical controls on the development and characteristics of Antarctic sea ice biological communities-a review and synthesis. Deep Sea Res. I 41, 1583-1604 (1994).

51. Strass, V. H. \& Nöthig, E. M. Seasonal shifts in ice edge phytoplankton blooms in the Barents Sea related to the water column stability. Polar Biol. 16, 409-422 (1996).

52. Collins, L. G. et al. Evaluating highly branched isoprenoid (HBI) biomarkers as a novel Antarctic sea-ice proxy in deep ocean glacial age sediments. Quat. Sci. Rev. 79, 87-98 (2013).

53. Belt, S. T. et al. Identification of paleo Arctic winter sea ice limits and the marginal ice zone: optimised biomarker-based reconstructions of late Quaternary Arctic sea ice. Earth Planet. Sci. Lett. 431, 127-139 (2015).

54. Smik, L., Belt, S. T., Lieser, J. L., Armand, L. K. \& Leventer, A. Distributions of highly branched isoprenoid alkenes and other algal lipids in surface waters from East Antarctica: further insights for biomarker-based paleo sea-ice reconstruction. Org. Geochem. 95, 71-80 (2016).

55. Ribeiro, S. et al. Sea ice and primary production proxies in surface sediments from a High Arctic Greenland fjord: spatial distribution and implications for palaeoenvironmental studies. Ambio 46, 106-118 (2017).

56. Wagner, A., Lohmann, G. \& Prange, M. Arctic river discharge trends since $7 \mathrm{ka}$ BP. Glob. Planet. Change 79, 48-60 (2011).

57. North Greenland Ice Core Project Members. High resolution record of Northern Hemisphere climate extending into the last interglacial period. Nature 431, 147-151 (2004).

58. Broecker, W. S. Was the Younger Dryas triggered by a flood? Science 312, 1146-1148 (2006).

59. Not, C. \& Hillaire-Marcel, C. Enhanced sea-ice export from the Arctic during the Younger Dryas. Nat. Commun. 3, 1-5 (2012).

60. Fagel, N., Not, C., Gueibe, J., Mattielli, N. \& Bazhenova, E. Late Quaternary evolution of sediment provenances in the Central Arctic Ocean: mineral assemblage, trace element composition and $\mathrm{Nd}$ and $\mathrm{Pb}$ isotope fingerprints of detrital fraction from the Northern Mendeleev Ridge. Quat. Sci. Rev. 92, 140-154 (2014).
61. Scott, D. B., Schell, T., St-Onge, G., Rochon, A. \& Blasco, S. Foraminiferal assemblage changes over the last 15,000 years on the Mackenzie-Beaufort Sea Slope and Amundsen Gulf, Canada: implications for past sea ice conditions. Paleoceanography 24, PA2219 (2009).

62. Keigwin, L. D., Donnelly, J. P., Cook, M. S., Driscoll, N. W. \& Brigham-Grette, J. Rapid sea-level rise and Holocene climate in the Chukchi Sea. Geology 34, 861-864 (2006).

63. Hill, J. C. \& Driscoll, N. W. Paleodrainage on the Chukchi shelf reveals sea level history and meltwater discharge. Mar. Geol. 254, 129-151 (2008).

64. England, J. H. \& Furze, M. F. A. New evidence from the western Canadian Arctic Archipelago for the resubmergence of Bering Strait. Quat. Res. 70, 60-67 (2008)

65. Dyke, A. S. \& Savelle, J. M. Holocene history of the Bering Sea bowhead whale (Balaena mysticetus) in its Beaufort Sea summer grounds off Southwestern Victoria Island, Western Canadian Arctic. Quat. Res. 55, 371-379 (2001).

66. Dyke, A. S., Dale, J. E. \& McNeely, R. N. Marine molluscs as indicators of environmental change in glaciated North America and greenland during the last 18000 Years. Geogr. Phys. Quat. 50, 125-184 (1996).

67. Belt, S. T., Smik, L., Köseoglu, D., Knies, J. \& Husum, K. A novel biomarkerbased proxy for the spring phytoplankton bloom in Arctic and sub-arctic settings-HBI T25. Earth Planet. Sci. Lett. 523, 115703 (2019).

68. Fietz, S., Huguet, C., Rueda, G., Hambach, B. \& Rosell-Melé, A. Hydroxylated isoprenoidal GDGTs in the Nordic Seas. Mar. Chem. 152, 1-10 (2013).

69. Klotsko, S., Driscoll, N. \& Keigwin, L. Multiple meltwater discharge and ice rafting events recorded in the deglacial sediments along the Beaufort Margin, Arctic Ocean. Quat. Sci. Rev. 203, 185-208 (2019).

70. Sachs, J. P. et al. An Arctic Ocean paleosalinity proxy from $\delta 2 \mathrm{H}$ of palmitic acid provides evidence for deglacial Mackenzie River flood events. Quat. Sci. Rev. 198, 76-90 (2018).

71. Spielhagen, R. F., Erlenkeuser, H. \& Siegert, C. History of freshwater runoff across the Laptev Sea (Arctic) during the last deglaciation. Glob. Planet. Change 48, 187-207 (2005).

72. Nørgaard-pedersen, N. et al. Arctic Ocean during the Last Glacial Maximum: Atlantic and polar domains of surface water mass distribution and ice cover. Paleoceanography 18, 1-19 (2003).

73. Stein, R. et al. The last deglaciation event in the eastern central Arctic. Ocean Sci. 264, 692-696 (1994).

74. Poore, R. Z., Osterman, L., Hole, W. \& Hole, W. Late Pleistocene and Holocene meltwater events in the western Arctic Ocean. Geology 27, 759-762 (1999).

75. Stein, R., Fahl, K. \& Müller, J. Proxy reconstruction of Cenozoic Arctic Ocean sea ice history-from IRD to IP25. Polarforschung 82, 37-71 (2012).

76. Häggi, C. et al. Modern and late Pleistocene particulate organic carbon transport by the Amazon River: Insights from long-chain alkyl diols. Geochim. Cosmochim. Acta 262, 1-19 (2019).

77. Breckenridge, A. The Tintah-Campbell gap and implications for glacial Lake Agassiz drainage during the Younger Dryas cold interval. Quat. Sci. Rev. 117, 124-134 (2015).

78. Praetorius, $\mathrm{S}$. et al. The role of Northeast Pacific meltwater events in deglacial climate change. Sci. Adv. 6, eaay2915 (2020).

79. Boden, P., Fairbanks, G., Wright, D. \& Burckle, H. High-resolution stable isotope records from southwest Sweden: the drainage of the Baltic Ice Lake and Younger Dryas ice margin oscillations. Paleoceanography 12, 39-49 (1997).

80. Schell, T. M., Scott, D. B., Rochon, A. \& Blasco, S. Late quaternary paleoceanography and paleo-sea ice conditions in the Mackenzie Trough and Canyon, Beaufort Sea. Can. J. Earth Sci. 45, 1399-1415 (2008).

81. Andrews, J. T. \& Dunhill, G. Early to mid-Holocene Atlantic water influx and deglacial meltwater events, Beaufort Sea slope, Arctic Ocean. Quat. Res. 61, 14-21 (2004).

82. Winterfeld, M. et al. Deglacial mobilization of pre-aged terrestrial carbon from degrading permafrost. Nat. Commun. 9, 3666 (2018).

83. Meyer, V. D. et al. Permafrost-carbon mobilization in Beringia caused by deglacial meltwater runoff, sea-level rise and warming. Environ. Res. Lett. 14, 085003 (2019).

84. Stein, R., Fahl, K., Dittmers, K., Nissen, F. \& Stepanets, O. V. Holocene siliciclastic and organic carbon fluxes in the Oh and Yenisei estuaries and the adjacent inner Kara Sea: Quantification, variability, and paleoenvironmental implications. In Siberian River Run-off in the Kara Sea: Characterisation, Quantification, Variability and Environmental Significance 401-432 (Elsevier, Amsterdam, 2003).

85. Stein, R. \& Fahl, K. The Kara Sea: distribution, sources, variability and burial of organic carbon. in The Organic Carbon Cycle in the Arctic Ocean 213-237 (Springer-Verlag, Berlin, 2004).

86. Pearce, C. et al. Heinrich 0 on the east Canadian margin: source, distribution, and timing. Paleoceanography 30, 1613-1624 (2015).

87. Blaauw, M. \& Christeny, J. A. Flexible paleoclimate age-depth models using an autoregressive gamma process. Bayesian Anal 6, 457-474 (2011). 
88. Blaauw, M. \& Christen, J. A. Bacon Manual-v2.3.3 (2013).

89. Reimer, P. J. et al. Intcal13 and Marine13 Radiocarbon Age Calibration Curves 0-50,000 Years Cal Bp. Radiocarbon 55, 1869-1887 (2013).

90. Brown, T. A. \& Belt, S. T. Novel tri- and tetra-unsaturated highly branched isoprenoid (HBI) alkenes from the marine diatom Pleurosigma intermedium. Org. Geochem. 91, 120-122 (2016).

91. Boon, J. J. et al. Black Sea sterol-a molecular fossil for dinoflagellate blooms. Nature 277, 125-127 (1979).

92. Versteegh, G., Bosch, H. \& De Leeuw, J. Potential palaeoenvironmental information of C24 to C36 mid-chain diols, keto-ols and mid-chain hydroxy fatty acids; a critical review. Org. Geochem. 27, 1-13 (1997).

93. Rampen, S. W. et al. Long chain 1,13- and 1,15-diols as a potential proxy for palaeotemperature reconstruction. Geochim. Cosmochim. Acta 84, 204-216 (2012).

94. Stein, R. \& Macdonald, R. W. The Organic Carbon Cycle in the Arctic Ocean (Springer-Verlag, Berlin, 2004).

95. Wu, J. et al. Biomarker data of sediment core ARA04C/37, Beaufort Sea, Arctic Ocean. PANGAEA https://doi.org/10.1594/PANGAEA.915048 (2020).

96. Peltier, W. R., Argus, D. F. \& Drummond, R. Space geodesy constrains ice age terminal deglaciation: the global ICE-6G_C (VM5a) model. J. Geophys. Res. Solid Earth 120, 450-487 (2015).

\section{Acknowledgements}

We gratefully thank the professional support of the captain and crew of RV Araon on the expedition ARA04C. We thank Shizhu Wang for generating ice sheet maps. Thanks to Simon Belt (University of Plymouth/UK) for providing the 7-HND standard for $\mathrm{IP}_{25}$ quantification. We acknowledge support by the Open Access Publication Funds of Alfred Wegener Institute Helmholtz Centre for Polar and Marine Research (AWI) and China Scholarship Council for financial support. This research is also supported by the Basic Core Technology Development Program for the Oceans and the Polar Regions (NRF2015M1A5A1037243) from the National Research Foundation of Korea funded by the Ministry of Science and ICT. Open Access funding enabled and organized by Projekt DEAL.

\section{Author contributions}

R.S. designed this study. S.N. performed field work and sampling. J.W., K.F., and J.H. conducted biomarker analyses, evaluation, and quality control. N.S. and S.N. carried out bulk parameter analyses. J.W. identified foraminifers for age control, and G.M. conducted radiocarbon dating. W.G. measured ${ }^{210} \mathrm{~Pb}$ for age constraint of surface sediments. J.W. wrote the first version of the paper with input from R.S. All authors contributed to the data interpretation and writing of the final version of the paper.

\section{Competing interests}

The authors declare no competing interests.

\section{Additional information}

Supplementary information is available for this paper at https://doi.org/10.1038/s43247 020-00028-z.

Correspondence and requests for materials should be addressed to J.W.

Peer review information Primary handling editor: Joe Aslin.

Reprints and permission information is available at http://www.nature.com/reprints

Publisher's note Springer Nature remains neutral with regard to jurisdictional claims in published maps and institutional affiliations.

cc (i) Open Access This article is licensed under a Creative Commons Attribution 4.0 International License, which permits use, sharing, adaptation, distribution and reproduction in any medium or format, as long as you give appropriate credit to the original author(s) and the source, provide a link to the Creative Commons license, and indicate if changes were made. The images or other third party material in this article are included in the article's Creative Commons license, unless indicated otherwise in a credit line to the material. If material is not included in the article's Creative Commons license and your intended use is not permitted by statutory regulation or exceeds the permitted use, you will need to obtain permission directly from the copyright holder. To view a copy of this license, visit http://creativecommons.org/ licenses/by/4.0/.

(C) The Author(s) 2020 